\title{
TRANSDERMAL FENTANYL PATCH FOR ACUTE PAIN CONTROL AFTER SHORT INTRAHOSPITAL STAY
}

\author{
Matas Pažūsis ${ }^{1}$, Kristijonas Jasaitis ${ }^{2}$, Erika Keršytė ${ }^{2}$, Andrius Macas ${ }^{3}$, Žilvinas Endzinas ${ }^{2}$ \\ ${ }^{1}$ Faculty of Medicine, Medical Academy, Lithuanian University of Health Sciences, Kaunas, Lithu- \\ ania, ${ }^{2}$ Department of Surgery, Medical Academy, Lithuanian University of Health Sciences, Kaunas, \\ Lithuania, ${ }^{3}$ Department of Anesthesiology, Medical Academy, Lithuanian University of \\ Health Sciences, Kaunas, Lithuania
}

Keywords: analgesia, enhanced recovery, opioids, transdermal application, surgery, NSAID.

\begin{abstract}
Summary
Transdermal fentanyl patch (TFP) is used for alleviation of chronic pain, while scientific evidence regarding its use for acute pain is insufficient.

Purpose. To compare the effects of pain control by non-steroidal anti-inflammatory drug (NSAID) and TFP and the restrictions in daily activities in patients following elective minor surgical interventions.

Patients and methods. Prospective, randomised, casecontrolled study included patients aged $\geq 18$ years who underwent elective cholecystectomy, gastric fundoplication or inguinal hernia repair. All randomised patients (fentanyl prescription group, FG, and control group, CG, 62 cases each) were administered dressing plasters for the first three post-operative days; the FG patients received $50 \mathrm{mcg} / \mathrm{h}$ TFP under the plaster. Within the 4 post-operative days, the patients of both groups received diclofenac on demand. Post-operative pain at rest and during movement was evaluated using the Visual Analogue Scale on the 1st, 2nd, 3rd, 4 th post-operative days. Daily activities using the Functional Activity Score were scored as 0 - no limitations, 1 - some limitations, 2 - severe limitations. Results. Pain both at rest and during movement on the first three post-operative days was lower in the FG; CG patients received 5 times more doses of diclofenac on demand on the 1st day after the surgery, with the higher need of NSAID during the next two days $(p<0.05)$. The total number of NSAID doses per patient administered on demand was $3.11 \pm 0.59$ in the $\mathrm{CG}$ and $0.73 \pm 0.16$ in the $\mathrm{FG}(\mathrm{p}<0.05)$. The influence of pain on daily activities on the 2 nd post-operative
\end{abstract}

day was scored as 0 by $92 \%$ patients and as 1 by $8 \%$ patients of the FG, versus $60 \%$ and $40 \%$ patients of the $\mathrm{CG}(\mathrm{p}<0.05)$.

Conclusion. Patients with TFP experienced significantly more effective pain control leading to less restricted daily activities and used less doses of NSAID within the first few post-operative days.

Plain Language Summary. Could a single long-lasting dose of transdermal fentanyl patch serve as an alternative to uncontrolled consumption of non-steroid anti-inflammatory drugs when dealing with early post-operative pain in patients following a hospital discharge after an elective minor surgery? Our conclusion suggests that the answer is "yes", if the riskbenefits balance is evaluated.

\section{Introduction}

Today it is obvious, both from evidence-based literature as well as clinical practice, that uncontrolled post-operative pain results in the development of post-surgical complications, poor healing and functioning, and impaired quality of life [1-3]. Early post-operative pain triggers the development of chronic pain in 10\%-60\% of patients following common surgical procedures, that persists for months after the surgery $[4,5]$. In order to reduce the incidence and intensity of acute pain immediately after the surgery as well as to prevent its progression into chronic pain, more aggressive analgesic measures are required [3,6-8].

Transdermal fentanyl application (FTA) is widely used for the alleviation of chronic pain [9-12]. Fentanyl is slowly released and absorbed through the skin where it reaches the blood flow. FTA ensures prolonged analgesic effect and thus may help prevent repeated doses of non-steroidal anti-inflammatory medication (NSAID). Scientific evidence regar- 
ding the use of FTA for acute pain management is controversial and insufficient [13-18]. We hypothesized that FTA might help to control post-operative acute pain and to improve early mobilization after elective minor surgery.

The aim of this study was to compare the effects of pain control by conventional NSAID and FTA in the acute period in patients who underwent pre-planned minor surgical interventions, as well as to compare restrictions in daily activities in both groups.

\section{Material and methods}

The study was conducted at the Department of Surgery of the Hospital of Lithuanian University of Health Sciences. This prospective, randomised, case-controlled study included 124 patients operated between May 1, and December 31, 2018. Ethical approval of this study has been provided by the Bioethics Center of Lithuanian University of Heath Sciences according to the protocol No. BEC - MF - 161 (December 21, 2017).

Inclusion criteria: 18 years of age or older; an elective type of surgery that allowed hospital discharge on the next day after the operation - either a cholecystectomy, a gastric fundoplication, an inguinal hernia repair using a laparoscopic technique, or an inguinal hernia repair by Shouldice or Lichtenstein; were not already taking opioid pain medication at the time of inclusion; willing to participate in this study. Exclusion criteria were any conditions of chronic pain, also the use of opioid painkillers at the time of inclusion. All eligible patients were informed about the purpose and the design of the study, were free to decide about their participation and confirmed their approval by signing the Informed Consent Forms. For purposes of randomisation, an equal number of envelopes had been prepared: 62 for the fentanyl prescription group (FG) and 62 for the control group (CG). The envelopes were opened randomly for each patient by the surgical trainees responsible for the randomization. At the end of the surgery all patients were administered a $5 \times 5 \mathrm{~cm}$ dressing plaster for the next three consecutive days; the FG patients received $50 \mathrm{mcg} / \mathrm{h}$ transdermal fentanyl patch (TFP) under the dressing plaster. None of the patients knew the type of the plaster they had received. Also, at the end of the surgery, all patients received paracetamol $1 \mathrm{~g}$ and ketoprofen
$100 \mathrm{mg}$ intravenously. On the first day after surgery, for pain management on demand, the patients of both groups received intramuscular injections of diclofenac $75 \mathrm{mg} / 3 \mathrm{~mL}$, and $75 \mathrm{mg}$ of oral diclofenac for the following 3 days.

All information concerning post-operative pain at rest and during movement was collected and recorded, either directly during the patients' stay at the hospital on the first day after the surgery, or by phone after the discharge. The latter interview also included questions on the patients' functional activities.

The intensity of post-operative pain was evaluated using the Visual Analogue Scale (VAS, where 0 represented "no pain", 1-3 points represented "mild pain", 4-6 points represented "medium pain", 7-8

Table 1. Demographic and surgical data of the study groups

\begin{tabular}{|l|c|c|c|c|}
\hline & $\begin{array}{c}\text { Fentanyl } \\
\text { group N (\%) }\end{array}$ & $\begin{array}{c}\text { Control } \\
\text { group N (\%) }\end{array}$ & Total N (\%) & $\mathrm{p}$ \\
\hline Patients & $62(50)$ & $62(50)$ & $124(100)$ & \\
Female & $35(56.5)$ & $38(61.3)$ & $73(59)$ & $\mathrm{p}>0.05$ \\
Male & $27(43.5)$ & $24(38.7)$ & $51(41)$ & $\mathrm{p}>0.05$ \\
\hline Age (years) & $58.30 \pm 16.12$ & $58.87 \pm 15.04$ & $57.58 \pm 15.55$ & $\mathrm{p}>0.05$ \\
\hline Surgical procedures: & $62(100)$ & $62(100)$ & $124(100)$ & $\mathrm{p}>0.05$ \\
Laparoscopic & $30(48.4)$ & $28(45.2)$ & $58(46.8)$ & $\mathrm{p}>0.05$ \\
cholecystectomy & $12(20.0)$ & $8(13.0)$ & $20(16.1)$ & $\mathrm{p}>0.05$ \\
Laparoscopic hernia & & $20(32.2)$ & $33(26.6)$ & $\mathrm{p}>0.05$ \\
repair & $13(20.3)$ & $6(9.6)$ & $13(10.5)$ & $\mathrm{p}>0.05$ \\
Open hernia repair & $7(11.3)$ & & & \\
Laparoscopic & & & & \\
gastric fundoplication & & & & \\
\end{tabular}

Table 2. The intensity of pain on the first day after the surgery, at rest Abbreviations: VAS - Visual Analogue Scale

\begin{tabular}{|l|c|c|c|}
\hline \multicolumn{4}{|c|}{ VAS of pain at rest (from 0 to 10) } \\
\hline Post-operative days & Fentanyl group & Control group & $\mathrm{p}$ \\
\hline 1 & $0.5 \pm 0.11$ & $1.28 \pm 0.13$ & $\mathrm{p}<0.05$ \\
\hline 2 & $0.29 \pm 0.93$ & $1.44 \pm 0.12$ & $\mathrm{p}<0.05$ \\
\hline 3 & $0.21 \pm 0.07$ & $0.80 \pm 0.08$ & $\mathrm{p}<0.05$ \\
\hline 4 & $0.21 \pm 0.07$ & $0.18 \pm 0.06$ & $\mathrm{p}>0.05$ \\
\hline
\end{tabular}

Table 3. The intensity of pain on the first day after the surgery, during movement

Abbreviations: VAS - Visual Analogue Scale

\begin{tabular}{|l|l|l|l|}
\hline \multicolumn{4}{|c|}{ VAS of pain during movement (from 0 to 10) } \\
\hline Post-operative days & Fentanyl group & Control group & $\mathrm{p}$ \\
& & & \\
\hline 1 & $1.11 \pm 0.17$ & $2.54 \pm 0.15$ & $\mathrm{p}<0.05$ \\
\hline 2 & $0.61 \pm 0.14$ & $2.57 \pm 0.15$ & $\mathrm{p}<0.05$ \\
\hline 3 & $0.52 \pm 0.13$ & $1.85 \pm 0.12$ & $\mathrm{p}<0.05$ \\
\hline 4 & $1.05 \pm 0.15$ & $0.85 \pm 0.09$ & $\mathrm{p}>0.05$ \\
\hline
\end{tabular}


points meant "severe pain" and 9-10 points meant "unbearable pain") following 8 hours after the surgery as well as on the subsequent 2 nd, 3rd and 4th post-operative days both at rest and during movement.

Limitations in daily activities were recorded using the Functional Activity Score (FAS) in the following manner: 0 meaning "no limitations", 1 - "some limitations", and 2 - "severe limitations", ie difficulties or need for assistance with basic daily activities that one is expected to perform independently - personal hygiene, getting dressed, feeding, getting in and out of bed, etc [19].

Statistical analysis was performed using SPSS 17.0 package, MannWhitney $U$ and exact Chi square test. For the testing of statistical hypotheses, $\mathrm{p}<0.05$ was used as statistically significant.

\section{Results}

The demographic and surgical characteristics of both groups are presented in Table 1.

Patient groups were comparable by mean age, gender and the type of surgery. The types of the surgery performed were as follows: 13 (10.5\%) laparoscopic gastric fundoplications, 58 (46.8\%) laparoscopic

Table 4. Need for non-steroidal anti-inflammatory drugs following surgery

Abbreviations: NSAID - non-steroidal anti-inflammatory drug

\begin{tabular}{|l|c|c|c|}
\hline \multicolumn{3}{|c|}{ NSAID doses received by patients (mean) } \\
\hline Post-operative days & Fentanyl group & Control group & $\mathrm{p}$ \\
\hline 1 & $0.19 \pm 0.05$ & $0.92 \pm 0.05$ & $\mathrm{p}<0.05$ \\
\hline 2 & $0.19 \pm 0.07$ & $1.16 \pm 0.08$ & $\mathrm{p}<0.05$ \\
\hline 3 & $0.11 \pm 0.05$ & $0.80 \pm 0.10$ & $\mathrm{p}<0.05$ \\
\hline 4 & $0.23 \pm 0.06$ & $0.23 \pm 0.59$ & $\mathrm{p}>0.05$ \\
\hline $\begin{array}{l}\text { Total doses } \\
\text { per patient }\end{array}$ & $0.73 \pm 0.16$ & $3.11 \pm 0.59$ & $\mathrm{p}<0.05$ \\
\hline
\end{tabular}

Table 5 Distribution of functional activity scores after the discharge from the hospital on the 2nd-4th post-operative days (FAS 0-2)

Abbreviations: FAS - Functional Activity Scores

Notes: ${ }^{*} p<0.05$

\begin{tabular}{|l|c|c|c|c|c|c|}
\hline FAS & \multicolumn{3}{|c|}{ Fentanyl group, patients } & \multicolumn{3}{c|}{ Control group, patients } \\
& 2-nd day & 3-rd day & 4-th day & 2-nd day & $\begin{array}{c}\text { 3-rd } \\
\text { day }\end{array}$ & 4-th day \\
\hline $\begin{array}{l}\text { 0 (no activity } \\
\text { limitation) }\end{array}$ & $57(92)$ & $57(92)$ & $61(98)$ & $37(60)$ & $49(79)$ & $60(97)$ \\
\hline $\begin{array}{l}\text { 1 (some activ- } \\
\text { ity limitation) }\end{array}$ & $5(8)^{*}$ & $5(8)$ & $1(2)$ & $25(40)^{*}$ & $13(21)$ & $2(2)$ \\
\hline $\begin{array}{l}\text { 2 (severe activ- } \\
\text { ity limitation) }\end{array}$ & 0 & 0 & 0 & 0 & 0 & 0 \\
\hline
\end{tabular}

cholecystectomies, 20 (16.1\%) laparoscopic hernioplasties, 33 (26.6\%) open hernioplasties (Shouldice or Lichtenstein methods).

Pain both at rest (Table 2) and during movement (Table 3 ) on the 1st, 2nd and 3rd post-operative days, according to the VAS, was statistically lower in the FG as compared to the CG. On the 4th post-operative day, pain intensity at rest and during movement did not differ between the two groups.

Due to more severe post-surgical pain the CG patients had greater demand for additional analgesia and received 5 times more doses of diclofenac on the first day after the surgery (Table 4). The need for NSAID for the CG patients remained also significantly higher for the next two post-operative days $(\mathrm{p}<0.05)$; this need appeared to be comparable with the FG patients on the 4th post-operative day only. The total number of NSAID doses used per patient on demand was $3.11 \pm 0.59$ in the CG, and $0.73 \pm 0.16$ in the FG $(\mathrm{p}<0.05)$.

The influence of pain on daily activities at home on the 2 nd post-operative day was scored as "no limitation" by 57 (92\%) patients and as "some limitation" by $5(8 \%)$ patients of the FG, while "no limitation" was scored by 37 $(60 \%)$ patients and as "some limitation" by 25 $(40 \%)$ patients of the CG $(\mathrm{p}<0.05)$ (Table 5).

Some adverse events were recorded in the FG patients only: 4 (6.45\%) patients experienced dizziness, 1 (1.61\%) had syncope, and 3 (4.83\%) suffered from nausea. All of them had their body mass index $>25$, were aged 67-83 years and were on regular antihypertension medications.

\section{Discussion}

An early discharge from the hospital is feasible when rapid recovery can be expected and when the risk of surgery-related and anaesthesia-related adverse effects (ie pain, nausea, fatigue) is low. The patients must feel fit enough, and symptom intensity must be so low that safe self-care can be ensured [20].

Despite our ability to control pain during and immediately after the surgery with the help of local anaesthetic agents, opioids, and cyclo-oxygenase (COX) inhibitors, the pain that persists after the surgical 
wound has healed remains a major clinical problem [21].

Given the rise in ambulatory and one-day surgeries worldwide, greater effort has been taken to assess post-operative recovery with the focus on analgesia and early mobilisation [22]. The fear of post-operative pain scares many patients awaiting surgery. Gan et al. published the results of a US National survey: before surgery, post-surgical pain was the most prominent concern among patients surveyed, with $80 \%$ of responders expressing concern about this issue. After the surgery, which in $50 \%$ of cases was performed in an outpatient setting, these concerns appeared to be true in $85.7 \%$, and $75.5 \%$ of these patients scored their pain as moderate, severe or extreme; $87.9 \%$ of inpatients and $79.2 \%$ of outpatients reported pain after hospital discharge [23]. Presence and intensity of acute post-operative pain are major risk factors for the development of chronic post-operative pain that occurs in $10 \%-50 \%$ of patients, which is both distressing and reduces the quality of life $[8,21,22]$.

Opioid analgesia remains the mainstay of acute postoperative pain management, providing high-quality effective pain relief despite its potential side effects. Opioid abuse, however, has reached epidemic proportions in the United States, raising awareness of opioid abuse as a public health issue. Dealing with an opioid epidemic firstly requires that responsible use of opioids is medically warranted [24-27].

The use of non-opioid medication is often enough for functional relief of pain [4,28-30]. Non-opioids play an everincreasing role in the treatment of post-operative pain; either on their own for mild to moderate pain management, or in combination with other analgesic approaches, in particular opioids, when the pain is severe. According to the practice recommendations, unless contraindicated, patients should receive an around-the-clock regimen of NSAID for acute post-operative pain control as post-operative pain is the type of acute pain due to surgical damage of the tissue with an inflammatory reaction [31]. However, patients are not always satisfied with analgesic effects of NSAID, and NSAID appear to be a common cause of adverse drug events (ADEs), accounting for $25 \%$ of ADEs reported in the United Kingdom and 21\% in the United States [32]. NSAID could lead to the occurrence of acute kidney or liver injury, cardiovascular complications and gastrointestinal disturbances such as dyspepsia, heartburn, nausea, vomiting, bleeding or perforation as well as various neurological abnormalities, etc. [33-40].

TFP is an alternative to $\mathrm{i} / \mathrm{v}$ or oral opioids. These patches provide continuous medication for 2 to 3 days which leads to fewer opioid-related adverse events and pain control compared to intravenous opioids. Specificity of the transdermal route includes the slow desired effect as levels of fentanyl concentration in the plasma reach a plateau approximately 12-24 hours after the application of the patch and decline slowly following the removal of the patch (at $72 \mathrm{~h}$ ). The increase of fentanyl concentration in the plasma occurs slower in elderly patients [6,41-42]. The idea to use TFP was based on the personal experience of one of the authors in dealing with post-operative pain following a hospital discharge even after a minimal surgery. The analgesic effects of NSAID are short-lived, therefore additional doses, even exceeding the daily recommended doses, or the use of over-the-counter (OTC) analgesia is required. Widespread availability of OTC analgesics and the limited knowledge of analgesic risk by consumers and thus improper use of these drugs could potentially present a serious health risk $[43,44]$.

A rather alarming population-based cross-sectional study from the Netherlands showed that OTC NSAID were used by $30 \%$ of the general population, and $13 \%$ of high-risk patients with gastrointestinal, cardiovascular or renal disorders. Moreover, at least 333,000 Dutch adults use OTC NSAID in dosages exceeding the maximum at any given time [45]. Evidence of such high levels of uncontrolled use of OTC NSAID as shown by the above study raises concerns regarding potential epidemic risks of damaging OTC NSAID side effects across other populations.

By applying TFP, we expected to achieve longer lasting analgesia following the discharge from the hospital. Our patients who were administered TFP immediately post-surgery experienced significantly lower intensity of pain on the three consecutive post-operative days both at rest and during movement as compared to the control group.

Because of more intense pain, patients of the control group were likely to require more additional doses of NSAID (although their pain rating according to VAS may be evaluated as "mild"): on the 1st day following the surgery they received nearly 5 times more doses of NSAID, on the 2 nd day they needed over 6 times more doses, and on the 3rd day they were administered 7.3 times more doses of NSAID as compared to the fentanyl group patients; only on the 4th day the number of additional NSAID doses levelled across both groups.

Our study demonstrated that analgesia by applying TFP after minor surgical procedures and during short-term hospital stays allowed for sufficient analgesia within the initial few days following the surgery and helped to reduce the number of additionally required NSAID doses by 4.3 times.

Six patients in the fentanyl group experienced adverse effects (dizziness, nausea, syncope); all of these patients were 67 years or older. This raises the hypothesis that elderly patients may need TFP of a lower release. Analgesic effects as well as adverse effects when using TFP may be dose-de- 


\section{8}

pendent, as demonstrated by Gupta et al., who applied TFP 3 hours prior to the surgery in order to assess the difference in mean duration and the quality of post-spinal analgesia in patients who underwent elective abdominal hysterectomy [46]. Patients of Group I received placebo patch, Group II - $25 \mathrm{mcg} / \mathrm{h}$ TFP, Group III - $50 \mathrm{mcg} / \mathrm{h}$ TFP. The mean difference of VAS pain score was significantly lower in Group III and Group II. The requirement of rescue analgesic dose was significantly lower in Group II, and no rescue analgesic was needed in Group III ( $\mathrm{p}=0.00$ ), with side effects of nausea and vomiting in one patient from Group II and in three patients from Group III ( $>>0.05)$

There are some limitations to our study. Firstly, we did not measure the fentanyl plasma levels. But the results of our study regarding the timing of the analgesic effects of the fentanyl transdermal patch are consistent with the results of a study from South Korea[41]. The authors used TFP (25 $\mathrm{mcg} / \mathrm{h}$ ) for alleviation of post-surgical pain following laparoscopic cholecystectomies. They applied TFP 14 hours prior to surgery which allowed them to reach a peak $(3.27+-0.34$ nanog $/ \mathrm{mL}$ ) in the plasma fentanyl levels of their study group one hour following the operation. The authors conclude that FTA 12-14 hours prior to surgery ensures maximum fentanyl plasma levels immediately after the surgery which are then maintained at slightly lower levels for 48 hours post-surgery. Our aim was to ensure sufficient analgesia after the patient is discharged from the hospital, and, similar to the authors of the above-mentioned study, we observed favourable analgesic effects for around 60 hours when the risk of post-operative pain is at its peak, as observed in our control group.

Secondly, our study populations were not homogeneous in terms of the type of surgery, although all of them can be attributed to the minor surgery group - laparoscopic repair of inguinal hernia, gastric fundoplication, cholecystectomy as well as open repair of inguinal hernia. Moreover, the size of our study group was too small to allow reliable data analysis based on performed surgical procedure. Large-scale prospective studies might help to confirm the safety and efficacy of a single FTA dose as a part of multimodal analgesia during the early post-operative period after different elective minor surgeries.

\section{Conclusion}

Patients administered with FTA experienced significantly more effective pain control leading to less restricted daily activity within the first few post-operative days. Although NSAID could not be avoided entirely, the consumption of these drugs proved significantly lower in the group of patients administered with TFP. TFP should be used with caution in elderly patients due to potential risk of adverse effects.

\section{Acknowledgments}

We thank Mrs Aiste Smith for English language proofreading and editing services.

Patient consent for publication

Informed Consent.

Ethics Approval

Center of Bioetics of Lithuanian University of Health approved this study on December 21, 2017 No. BEC-MF-161.

Data Availability Statement

Data is available upon reasonable request.

Author Contributions

All authors contributed to data analysis, drafting or revising the article, gave final approval of the version to be published, and agree to be accountable for all aspects of the work.

Disclosure

The author reports no conflicts of interest in this work.

\section{References}

1. Glowacki D. Effective pain management and improvements in patients' outcomes and satisfaction. Crit Care Nurse. 2015;35(3):33-41. https://doi.org/10.4037/ccn2015440

2. Breivik H, Borchgrevink PC, Allen SM, et al. Assessment of pain. Br J Anaesth. 2008; 101(1):17-24. https://doi.org/10.1093/bja/aen103

3. Gan TJ. Poorly controlled postoperative pain: prevalence, consequences, and prevention. J Pain Res. 2017;10:2287-2298. https://doi.org/10.2147/JPR.S144066

4. Reddi D. Preventing chronic postoperative pain. Anaesthesia. 2016;71 Suppl 1:64-71. https://doi.org/10.1111/anae.13306

5. Ravindran D. Chronic postsurgical pain: prevention and management. J Pain Palliat Care Pharmacother. 2014;28(1):51-3. https://doi.org/10.3109/15360288.2013.879249

6. Lovich-Sapola J, Smith CE, Brandt CP. Postoperative pain control. Surg Clin North Am. 2015; 95(2):301-18. https://doi.org/10.1016/j.suc.2014.10.002

7. Tan M, Law LS, Gan TJ. Optimizing pain management to facilitate enhanced recovery after surgery pathways. Can J Anaesth. 2015;62(2):203-18. https://doi.org/10.1007/s12630-014-0275-x

8. Dunkman WJ, Manning MW. Enhanced recovery after surgery and multimodal strategies for analgesia. Surg Clin North Am. 2018;98 (6):1171-1184. https://doi.org/10.1016/j.suc.2018.07.005

9. Park JH, Kim JH, Yun SC, Roh SW, Rhim SC, Kim CJ, Jeon SR. Evaluation of efficacy and safety of fentanyl transdermal patch (Durogesic D-TRANS) in chronic pain. Acta Neurochir (Wien). 2011;153(1):181-90. https://doi.org/10.1007/s00701-010-0785-4

10. Radbruch L, Elsner F. Clinical experience with transdermal fentanyl for the treatment of cancer pain in Germany. Keio J Med. 2004;53(1):23-9.

https://doi.org/10.2302/kjm.53.23 
11. Kawai K, Yoshizawa K, Fujie M, Kobayashi H, Ogawa Y, Yajima T. Use of fentanyl patch for treatment of moderate-tosevere chronic noncancer pain: postmarketing surveillance of medical practice in japan using a risk minimization action plan. Pain Pract. 2017;17(2):239-248.

https://doi.org/10.1111/papr.12454

12. Dima D, Tomuleasa C, Frinc I, et al. The use of rotation to fentanyl in cancer-related pain. J Pain Res. 2017;10:341-348. https://doi.org/10.2147/JPR.S121920

13. Matsumoto S, Matsumoto K, Iida $\mathrm{H}$. Transdermal fentanyl patch improves post-operative pain relief and promotes early functional recovery in patients undergoing primary total knee arthroplasty: a prospective, randomised, controlled trial. Arch Orthop Trauma Surg. 2015;135(9):1291-7. https://doi.org/10.1007/s00402-015-2265-z

14. Choi HS, Kim KO, Chun HJ, et al. The efficacy of transdermal fentanyl for pain relief after endoscopic submucosal dissection: a prospective, randomised controlled trial. Dig Liver Dis. 2012; 44(11):925-9.

https://doi.org/10.1016/j.dld.2012.06.015

15. Kaye AD, Urman RD, Rappaport Y, et al. Multimodal analgesia as an essential part of enhanced recovery protocols in the ambulatory settings. J Anaesthesiol Clin Pharmacol. 2019;35(Suppl 1):S40-S45.

16. Kuczyńska K, Grzonkowski P, Kacprzak Ł, Zawilska JB. Abuse of fentanyl: An emerging problem to face. Forensic Sci Int. 2018;289:207-214.

https://doi.org/10.1016/j.forsciint.2018.05.042

17. Nair AS. Transdermal fentanyl patch in post-operative patients: Is it justified? Indian J Anaesth. 2017;61(8):682-683.

https://doi.org/10.4103/ija.IJA_349_17

18. Kwon Y, Hwang SM, Jang JS, et al. Effects of a preoperative transdermal fentanyl patch on proinflammatory cytokine and pain levels during the postoperative period: a randomized controlled trial. Surg Laparosc Endosc Percutan Tech. 2019;29(5):339-343.

https://doi.org/10.1097/SLE.0000000000000630

19. Zhu Y, Xie K, Yuan J, et al. Efficacy of oxycodone in intravenous patient-controlled analgesia with different infusion modes after laparoscopic radical surgery of cervical cancer a prospective, randomized, double-blind study. Medicine (Baltimore). 2019;98(34):e16810.

https://doi.org/10.1097/MD.0000000000016810

20. Beverly A, Kaye AD, Ljungqvist O, Urman RD. Essential elements of multimodal analgesia in enhanced recovery after surgery (ERAS) guidelines. Anesthesiol Clin. 2017;35(2):e115e143.

https://doi.org/10.1016/j.anclin.2017.01.018

21. Jakobsson JG. Pain management in ambulatory surgery - a review. Pharmaceuticals. 2014;7:850-65. https://doi.org/10.3390/ph7080850

22. Kehlet H, Jensen TS, Woolf CJ. Persistent postsurgical pain: risk factors and prevention. Lancet. 2006;367(9522):1618-25.
https://doi.org/10.1016/S0140-6736(06)68700-X

23. Kharasch ED, Brunt LM. Perioperative opioids and public health. Anesthesiology 2016;124 (4):960-5.

https://doi.org/10.1097/ALN.0000000000001012

24. Gan TJ, Habib AS, Miller TE, White W, Apfelbaum JL. Incidence, patient satisfaction, and perceptions of post-surgical pain: results from a US national survey. Curr Med Res Opin. 2014; 30(1):149-60.

https://doi.org/10.1185/03007995.2013.860019

25. Schaefer CP, Tome ME, Davis TP. The opioid epidemic: a central role for the blood brain barrier in opioid analgesia and abuse. Fluids Barriers CNS. 2017;14(1):32.

https://doi.org/10.1186/s12987-017-0080-3

26. Tan WH, Yu J, Feaman S, et al. Opioid medication use in the surgical patient: an assessment of prescribing patterns and use. J Am Coll Surg. 2018;227(2):203-211.

https://doi.org/10.1016/j.jamcollsurg.2018.04.032

27. Eid AI, DePesa C, Nordestgaard AT, et al. Variation of opioid prescribing patterns among patients undergoing similar surgery on the same acute care surgery service of the same institution: time for standardization? Surgery. 2018;64(5):926-930.

https://doi.org/10.1016/j.surg.2018.05.047

28. Yorkgitis BK, Brat GA. Postoperative opioid prescribing: getting it RIGHTT. Am J Surg. 2018;215(4):707-711.

https://doi.org/10.1016/j.amjsurg.2018.02.001

29. Schug SA1, Manopas A. Update on the role of non-opioids for postoperative pain treatment. Best Pract Res Clin Anaesthesiol. 2007;21(1):15-30.

https://doi.org/10.1016/j.bpa.2006.12.002

30. Pogatzki-Zahn E, Chandrasena C, Schug SA. Nonopioid analgesics for postoperative pain management. Curr Opin Anaesthesiol. 2014;27(5):513-9.

https://doi.org/10.1097/ACO.0000000000000113

31. Practice guidelines for acute pain management in the perioperative setting: an updated report by the american society of anesthesiologists task force on acute pain management. Anesthesiology 2012;116 (2):248-273.

https://doi.org/10.1097/ALN.0b013e31823c1030

32. Zhang X, Donnan PT, Bell S, Guthrie B. Non-steroidal anti-inflammatory drug induced acute kidney injury in the community dwelling general population and people with chronic kidney disease: systematic review and metaanalysis. BMC Nephrol. 2017;18(1):256.

https://doi.org/10.1186/s12882-017-0673-8

33. Cao YL, Tian ZG, Wang F, et al. Characteristics and clinical outcome of nonsteroidal anti-inflammatory drug-induced acute hepato-nephrotoxicity among Chinese patients. World J Gastroenterol. 2014;20(38):13956-65. https://doi.org/10.3748/wjg.v20.i38.13956

34. McGettigan P, Henry D. Use of non-steroidal anti-inflammatory drugs that elevate cardiovascular risk: an examination of sales and essential medicines lists in low-, middle-, and high-income 
countries. PLoS Med. 2013;10(2):e1001388.

https://doi.org/10.1371/journal.pmed.1001388

35. Walker C, Biasucci LM. Cardiovascular safety of non-steroidal anti-inflammatory drugs revisited. Postgrad Med. 2018;130(1):55-71.

https://doi.org/10.1080/00325481.2018.1412799

36. Gómez-Acebo I, Dierssen-Sotos T, de Pedro M,Pérez-Gómez B, et al. Epidemiology of non-steroidal anti-inflammatory drugs consumption in Spain. The MCC-Spain study. BMC Public Health. 2018;18(1):1134.

https://doi.org/10.1186/s12889-018-6019-z

37. Fine M. Quantifying the impact of NSAID-associated adverse events. Am J Manag Care. 2013;19(14 Suppl):s267-72.

38. Bidaut-Russell M, Gabriel SE. Adverse gastrointestinal effects of NSAIDs: consequences and costs. Best Pract Res Clin Gastroenterol. 2001;15(5):739-53.

https://doi.org/10.1053/bega.2001.0232

39. Lucas GNC, Leitão ACC, Alencar RL, Xavier RMF, Daher EF, Silva Junior GBD. Pathophysiological aspects of nephropathy caused by non-steroidal anti-inflammatory drugs. J Bras Nefrol. 2019;41(1):124-130.

https://doi.org/10.1590/2175-8239-jbn-2018-0107

40. Gunter BR, Butler KA, Wallace RL, Smith SM, Harirforoosh S. Non-steroidal anti-inflammatory drug-induced cardiovascular adverse events: a metaanalysis. J Clin Pharm Ther. 2017; 42(1):27-38.

https://doi.org/10.1111/jcpt.12484

41. Jang JS, Hwang SM, Kwon Y, et al. Is the transdermal fentanyl patch an efficient way to achieve acute postoperative pain control?: A randomized controlled trial. Medicine (Baltimore). 2018;97(51):e13768.

https://doi.org/10.1097/MD.0000000000013768

42. Thompson J P, Bower S. Liddle AM, Rowbotham D J. Perioperative pharmacokinetics of transdermal fentanyl in elderly and young adult patients. British Journal of Anaesthesia. 1998;81(2): 152-154.

https://doi.org/10.1093/bja/81.2.152

43. Paulose-Ram R, Hirsch R, Dillon C, Losonczy K, Cooper M, Ostchega Y. Prescription and non-prescription analgesic use among the US adult population: results from the third National Health and Nutrition Examination Survey (NHANES III). Pharmacoepidemiol Drug Saf. 2003;12(4):315-26.

https://doi.org/10.1002/pds.755

44. MacDonald TM, Beard K, Bruppacher R, et al. The safety of drugs for OTC use: what evidence is required for an NSAID switch? Pharmacoepidemiol Drug Saf. 2002;11(7):577-84. https://doi.org/10.1002/pds.736

45. Koffeman AR, Valkhoff VE, Celik S, et al. High-risk use of over-the-counter non-steroidal anti-inflammatory drugs: a population-based cross-sectional study. Br J Gen Pract. 2014; 64(621):e191-8.

https://doi.org/10.3399/bjgp14X677815
46. Gupta R, Ahmed F, Chatterjee R, Rathore M, Aggarwal A. Postspinal analgesic effect of transdermal fentanyl patch $(2.5$ $\mathrm{mg}$ and $5 \mathrm{mg}$ ) in abdominal hysterectomy: A randomized doubleblind control study. Indian J Pain. 2016;30:122-6.

https://doi.org/10.4103/0970-5333.186469

\section{ŪMINIO SKAUSMO MALŠINIMAS TRANSDERMINIU FENTANILIO PLEISTRU PO TRUMPALAIKIO POOPERACINIO LAIKOTARPIO LIGONINĖJE}

M. Pažūsis, K. Jasaitis, E. Keršytė, A. Macas, Ž. Endzinas

Raktažodžiai: analgezija, opioidai, transderminis fentanilio pleistras, chirurgija, nespecifiniai vaistai nuo uždegimo.

Santrauka

Transderminis fentanilio pleistras (TFP) vartojamas malšinti stiprų ilgalaikị skausmą, tačiau moksliniais tyrimais pagrịstos informacijos apie jo panaudojimo galimybes ūminio skausmo malšinimui nėra daug.

Tikslas. Palyginti pooperacinio nesteroidinių vaistų nuo uždegimo (NSAID) ir TFP efektyvumą mažinant skausmą ir jo sukeliamus kasdienès veiklos apribojimus po planinių „mažujų " pilvo operacijų.

Pacientai ir metodai. Perspektyvinio, atsitiktinių imčių tyrimo metu buvo tiriami 18 metu ir vyresni pacientai, kuriems buvo atliktos planinès laparoskopinès tulžies pūslès šalinimo, skrandžio antirefliuksinės (gastrofundoplikacijos) ar kirkšnies išvaržos šalinimo operacijos laparoskopu ar ,,atviru“ būdu. I tyrimą įtraukti pacientai buvo suskirstyti ị dvi grupes - 62 asmenys sudare fentanilio grupę (FG), kiti 62 - kontrolinę grupę (CG). Abiejų grupių pacientams pabaigus operacijas buvo užklijuojamas pleistras trims pooperacinėms paroms, bet FG grupeje po šiuo pleistru buvo priklijuojamas $50 \mathrm{mcg} / \mathrm{val}$ transderminis fentanilio pleistras. Per pirmąsias keturias dienas pooperacinio skausmo malšinimui pacientams pagal poreikị buvo skiriamas diklofenakas. Šiuo laikotarpiu kasdien buvo vertinamas skausmo intensyvumas ramybès metu, bei pacientams judant, naudojantis vizualine analogine skausmo skale. Kasdienès veiklos aktyvumo apribojimai vertinti naudojantis funkcinio aktyvumo balų sistema: 0 - nèra apribojimų, 1 - nežymūs apribojimai, 2 - ryškūs apribojimai.

Rezultatai. Pirmujų trijų pooperacinių dienų metu FG pacientai atžymėjo mažesnio intensyvumo skausmą ir ramybejje, ir judesių metu; tuo tarpu CG pacientai suvartojo 5 kartus daugiau diklofenako dozių per pirmają pooperacinę dieną, bei poreikis didesniam NSAID vartojimui buvo stebetas ir kitas dvi dienas $(\mathrm{p}<0.05)$. Bendras pagal poreikị suvartotų NSAID dozių skaičius sudare $3.11 \pm 0.59$ kontrolinès grupès pacientams, tuo tarpu FG jis siekè $0.73 \pm 0.16(\mathrm{p}<0.05)$. Skausmo įtaką kasdienei veiklai antrą pooperacinę dieną 0 balų ịvertino $92 \%$ FG pacientų bei 1 balu $8 \%$; atitinkamai kontrolinès grupés pacientų įvertinimai nuvo $60 \%$ ir $40 \%(\mathrm{p}<0.05)$.

Išvados. Pacientai po „mažųjų“ pilvo operacijų su TFP ankstyvuoju pooperaciniu laikotarpiu jautė efektyvesnį nuskausminimą, tuo pačiu ir mažiau ribotą kasdienị aktyvumą bei mažesnị papildomo nuskausminimo NSAID poreikị.

Adresas susirašinèti: zilvinas.endzinas@kaunoklinikos.lt

Gauta 2020-03-04 